\title{
DEFENDING DEFENDERS: REMARKS ON NICHOL AND PIERCE
}

\author{
MARSHALL J. BREGER†
}

\section{INTRODUCTION}

Dean Nichol and Professor Pierce have presented two interesting views of Lujan v. Defenders of Wildlife. ${ }^{1}$ Both read this case as the first instance in which the U.S. Supreme Court has limited the power of Congress to confer standing on individuals to sue. Dean Nichol views this limitation as part of Justice Scalia's "broader agenda" of reducing the role of the judiciary in government policymaking. ${ }^{2}$ Professor Pierce views it as part of a different project: Reducing the role of Congress in government policymaking. ${ }^{3}$

Both Nichol and Pierce, as devotees of grand theory, are interested in analyzing Scalia's "agenda," however described. They view Defenders as a fundamental change in the Court's standing jurisprudence, in part because of the symbolism they and their fellow detractors impart to the decision. In contrast, I am apparently a miniaturist, at least when it comes to the possibility of grand theories and "broader agendas." I say this because I do not read Defenders as a major departure in the law of standing. The case merely applied a settled principle-that the case or controversy requirement in Article III of the Constitution requires a

$\dagger$ Senior Fellow, Heritage Foundation, Washington, D.C. B.A., M.A. 1967, University of Pennsylvania; B. Phil. 1970, Oriel College, Oxford University; J.D. 1973, University of Pennsylvania.

I want to thank Edward Sieger, Steven Mandel, and Nate Spiller of the Department of Labor for their valuable insights and assistance in the preparation of these remarks presented at a symposium on Lujan $v$. Defenders of Wildlife held at Duke University School of Law on January 21, 1993. These remarks were prepared while the author served as Solicitor of Labor, U.S. Department of Labor.

1. 112 S. Ct. 2130 (1992).

2. Gene R. Nichol, Jr., Justice Scalia, Standing, and Public Law Litigation, 42 DUKE L.J. 1141, 1166 (1993).

3. Richard J. Pierce, Jr., Lujan v. Defenders of Wildlife: Standing as a Judicially Imposed Limit on Legislative Power, 42 DUKE L.J. 1170 (1993). 
plaintiff to prove a particularized injury or injury in fact-to a situation where Congress did not define such an injury and the plaintiff did not otherwise prove that it would suffer cognizable injuries. Like Justice Kennedy, I do not read Justice Scalia's opinion to hold that Congress cannot confer standing by defining an injury and relating it to a class of persons entitled to sue. ${ }^{4}$

I also believe the decision correctly insisted on proof of the required injury. The suggestion of Dean Nichol and Professor Pierce, that Congress can eliminate the injury in fact requirement introduces a novel and unwise departure from established principles of standing. That requirement is an important curb on judicial power, which otherwise can serve not only to further the interests of individuals or groups whom judges perceive as beneficiaries of a statute, but to further the interests of entities the statute was supposed to regulate. While at the Department of Labor, I had a first-hand example of the dangers of such overreaching under the Occupational Safety and Health Act (OSHA). In AFL-CIO v. $O S H A,{ }^{5}$ the U.S. Court of Appeals for the Eleventh Circuit recently overturned numerous air contaminant exposure limits on a challenge by several industries that never claimed to be affected by most of the limits. Relying on Defenders, the Department sought rehearing in the Eleventh Circuit in hopes of reversing this judicial overreaching thus enlarging OSHA's ability to protect American workers. ${ }^{6}$

I will return to the Eleventh Circuit's decision later. First, I want to clarify what I see as the holding of Defenders. Next, I explain why I believe the decision was correctly decided. Finally, I explain why I do not believe the decision represents a radical change in the law of standing.

4. See Defenders, 112 S. Ct. at $2146-47$ (Kennedy and Souter, JJ., concurring in part and concurring in the judgment).

5. 965 F.2d 962 (11th Cir. 1992).

6. Petition for Rehearing and Suggestion for Rehearing En Banc at 4-6, AFL-CIO v. OSHA, 965 F.2d 962 (11th Cir. 1992) (No. 89-7815). The petition was denied and the Justice Department determined not to seek Supreme Court review of the Eleventh Circuit ruling. 54 Daily Lab. Rep. (BNA) A7 (Mar. 23, 1993). 


\section{The Holding of DEFENDERS: PlaintifFs FaILEd to PROVE INJURY IN FACT AND CONGRESS DID NOT OTHERWISE GRANT IT STANDING}

As Dean Nichol and Professor Pierce have discussed, Defenders arose when an environmental group challenged a regulation interpreting the Endangered Species Act (the Act) to require each federal agency to consult with the Secretary of Interior before funding projects in the United States or on the high seas that could affect an endangered species. The Court held that the plaintiff did not have standing to pursue the action. The Court's decision-and I leave out of this discussion that part of Justice Scalia's opinion which dealt with redressability, as it did not command a majority of the Court-had two lines of reasoning. First, the Court held that the plaintiff did not prove injury in fact under the Court's precedents. Second, the Court held that Congress did not grant the plaintiff standing in the statute.

\section{A. Plaintiff Failed to Prove "Imminent" and "Particularized" Inju- ries}

In holding that the plaintiff had not shown injury in fact to any of its members, the Court applied its precedents requiring such an injury to be "imminent" and "particularized." At the summary judgment stage, the affidavits of two Defenders' members showed a threatened, particularized injury but did not show that it was imminent. These affidavits showed that the members had traveled to habitats of endangered species to observe them and intended to return but did not state when they would do so. "Such 'some day' intentions-without any description of concrete plans, or indeed even any specification of when the some day will be" was not enough to confer standing.?

In rejecting Defenders' novel "nexus" theories, the Court applied its precedents requiring a particularized injury. The Court reasoned that, because the "ecosystem nexus" theory would give standing to any person who used any part of a "contiguous ecosystem," whether or not the part they used was affected by the allegedly unlawful action being challenged, it was inconsistent with earlier precedents. ${ }^{8}$ Similarly, the Court rejected the "animal nex-

7. Defenders, 112 .S. Ct. at 2138.

8. Id. at 2139 (citing Lujan v. National Wildlife Fed'n, 497 U.S. 871, 887-89 (1990); 
us" and "vocational nexus" theories, which sought standing for anyone interested in studying or seeing the endangered animals anywhere on the globe and for anyone with a "professional interest in such animals," because they did not show how a person with these interests would be harmed by the challenged action. ${ }^{9}$ In Justice Scalia's words, it was "beyond all reason" that "anyone who goes to see Asian elephants in the Bronx Zoo, [or] anyone who is a keeper ... in th[at] Zoo" can sue regarding a federally funded project in Sri Lanka. ${ }^{10}$ This part of the Court's decision did not make new law. It reemphasized and applied the well-established principle that standing requires a plaintiff to prove an injury that is imminent and particularized. None of the dissenting or concurring Justices disputed these requirements, though they had differing views on what a plaintiff has to prove to meet them. ${ }^{11}$

By the way, Richard Pierce, Cass Sunstein, and others argue that Congress could easily "fix" the standing problem by making a legislative finding that individuals suffer harm under the three nexus theories-"ecosystem nexus," "animal nexus," and "professional nexus." 12 Pierce assumes that it is obvious that Congress wants to do this. Indeed, he suggests that all Congress needs to do is make explicit what it meant and what is already implicit in the Act. ${ }^{13}$

I do not want to debate here whether Congress can, in fact, provide such a standing "fix." It seems likely, however, that Congress, even a Democratic Congress, will think twice before acting in ways that formally legitimate such New Age jurisprudential theories as "ecosystem nexus" or "animal nexus." If Congress was not explicit on these matters, it is likely because it did not want to be. That point should be kept in mind when someone suggests ignoring the need for particularized injury in the face of such "exotic" theories.

Sierra Club v. Morton, 405 U.S. 727, 735 (1972)).

9. Id.

10. Id.

11. See id. at 2152-54 (Blackmun and O'Connor, JJ., dissenting); id. at 2146 (Kennedy and Souter, JJ., concurring in part and concurring in the judgment); id. at 2147-49 (Stevens, J., concurring); see also id. at 2138 n.2; id. at 2140 n.3.

12. Pierce, supra note 3 , at $1181-82$.

13. Id. at 1181. 


\section{B. Congress Did Not Create a "Procedural Right" Sufficient to Confer Standing}

To return to Defenders, the second part of the Court's decision holds that the citizen suit provision of the Endangered Species Act, which allows "any person" to sue to redress violations of the Act, does not give standing to just "anyone" to sue for such violations. ${ }^{14}$ It is not clear whether the Court construed this provision, as the court of appeals did, to confer a "procedural right" on anyone to sue without any need to allege discrete injury-a point I will address later ${ }^{15}$-but the Court made it clear that Article III prevents Congress from doing so. ${ }^{16}$ The Court relied on a number of earlier cases that held that there is no Article III case or controversy when a person alleges only a generally available grievance about government. It explained that the particularized or discrete injury requirement of these cases is rooted in separation of powers concerns, specifically, that Congress not be able to transfer to courts the responsibility of the executive branch to "take Care that the Laws be faithfully executed."17 The Court also recognized, however, that under its precedents, statutes may establish categories of injury that may be alleged in support of standing, as long as the party seeking review has suffered a concrete injury. Thus, an individual can enforce procedural rights prescribed by statute, as long as "the procedures in question are designed to protect some threatened concrete interest, that is, the ultimate basis, of his standing."18

\section{DEFENDERS WAS CORRECT IN THESE HOLDINGS}

A. The Court Properly Reaffirmed That Injury in Fact Is a Core Element of Article III's Case or Controversy Requirement

The Court's most important holding was to reaffirm that injury in fact is a core element of Article III's case or controversy requirement. Probably the best way to demonstrate the Court's correctness on this point is to examine what would happen if Congress could eliminate the injury in fact requirement. If this

\footnotetext{
14. Defenders, 112 S. Ct. at $2142-43$.

15. See infra text accompanying notes $40-43$.

16. Defenders, $112 \mathrm{~S}$. Ct. at 2143-46.

17. U.S. CONST. art. II, $\S 3$.

18. Lujan v. Defenders of Wildlife, 112 S. Ct. 2130, 2143 n.8 (1992).
} 
were possible, I think the Court's fears about a transfer of executive power to the judiciary could well be realized.

For example, as I mentioned earlier in discussing the litigation over the Department of Labor's Occupational Safety and Health Act (OSHA) air contaminants standard, ${ }^{19}$ courts could easily use a citizen suit provision authorizing "any person" to sue to set aside regulations that neither the purported beneficiaries of a statute nor entities affected by the regulations have challenged. Essentially, this is what the U.S. Court of Appeals for the Eleventh Circuit did. In the permissible exposure limits case, although OSHA had promulgated 428 permissible exposure limits for chemicals, only twenty-three were challenged. Nonetheless, the Eleventh Circuit, sua sponte, vacated all 428 exposure limits. ${ }^{20}$ Keeping an injury in fact requirement grounded in Article III will prevent such judicial overreaching. The fact that the Department of Labor, in seeking rehearing of the Eleventh Circuit's decision suggests that sensible injury in fact requirements are not asserted by conservatives in order to promote any particular political result. Such requirements affect regulated firms and the benefitted public equally. Contra Pierce, I believe Defenders will cabin inappropriate policymaking by the judiciary.

In addition, even without judicial overreaching a citizen's suit provision which allows "any person" to sue violators and the regulating agency can be disruptive of an agency's operations. Again, this can be seen by examining what would happen if Congress decided to include such provisions, not just in environmental statutes, under which plaintiffs have brought a limited number of suits, but in other statutes, under which we can expect more private suits. Could Congress allow "any person" to sue for violations of generally applicable criminal laws, for example? I suspect that we would have not just what Justice Scalia termed the "full-time public interest law firm, as permanently in place as the full-time congressional lobby,"21 but also full-time advocacy groups dedicated to enforcing drug forfeitures and punishing rapes and robberies. At some point, such groups would challenge (or at least seriously interfere with) the government's enforcement policies.

19. See supra text accompanying notes 5-6.

20. AFL-CIO v. OSHA, 965 F.2d 962, 987 (11th Cir. 1992).

21. Antonin Scalia, The Doctrine of Standing as an Essential Element of the Separation of Powers, 17 SUfFolK U. L. REv. 881, 893 (1983). 
Another unhealthy consequence of allowing Congress to eliminate the injury in fact requirement could be disruption of the doctrines of ripeness and mootness, which have been characterized as "time-bound perspectives" on the injury inquiry. ${ }^{22}$ If you eliminate injury in fact, what basis is there for saying that a case is either not ripe (because an injury has not yet been felt in a concrete way) or moot (because there is no longer an injury)? The door is also open for courts to entertain collusive suits and issue advisory opinions. ${ }^{23}$ These possibilities would be a very real concern for the Department of Labor, which often interacts informally with members of the regulated public, for example, by issuing opinion letters under such statutes as the Employee Retirement Income Security Program (ERISA) ${ }^{24}$ and the Fair Labor Standards Act (FLSA), ${ }^{25}$ but resists attempts to litigate the views expressed in those letters in advance of an enforcement action. ${ }^{26}$

Another unwanted consequence, which the Court did not identify in Defenders, could be an expansion of the government's ability to exercise power over private citizens. For example, Congress could decide (as it did in the statute invalidated on Article III grounds in United States v. Evans ${ }^{27}$ ) to allow the government to appeal procedural rulings after criminal acquittals to obtain binding decisions on issues likely to arise in future cases. Another example could occur if Congress were to enact a hypothetical national abortion statute codifying procedural requirements involving notification and consent ${ }^{28}$ and providing a right for "any person" to sue. Such a statute would allow interest groups to litigate every attempted abortion in the country, contrary to the Article III holding in Diamond v. Charles. ${ }^{29}$ Similar statutes could overrule other Supreme Court decisions regarding taxpayer standing ${ }^{30}$

22. See 13 Charles A. Wright \& ARthuR R. Miller, Federal Practice and PROCEDURE \& 3531, at 350 (2d ed. 1984).

23. Cf. Gene R. Nichol, Jr., Rethinking Standing, 72 CAL. L. REv. 68, 91-92 (1984) (recognizing that Congress cannot authorize federal courts to issue advisory opinions).

24. 29 U.S.C. \& $1143(c)(1988)$.

25. 29 U.S.C. \& 204(d) (1988).

26. See, e.g., Taylor-Callahan-Coleman Counties Dist. Adult Probation Dep't v. Dole, 948 F.2d 953 (5th Cir. 1991).

27. 213 U.S. 297, 299-301 (1909).

28. The Court upheld state procedural notification and consent requirements in Planned Parenthood of S.E. Pa. v. Casey, 112 S. Ct. 2791 (1992).

29. 476 U.S. 54, 64-67 (1986).

30. See, e.g., Valley Forge Christian College v. Americans United for Separation of 
or First Amendment challenges ${ }^{31}$ and materially change the way that courts, litigants, and agencies do business.

Neither Dean Nichol nor Professor Pierce comes to grips with these consequences in arguing that the Defenders Court erred in its Article III analysis. The arguments they do make are also unpersuasive. Dean Nichol attacks the injury in fact requirement as a departure from the historical understanding of Article III, noting that qui tam and informer actions were allowable in colonial times and in the early period after adoption of the Constitution. ${ }^{32}$ This argument, which other scholars have accepted, ${ }^{33}$ is not compelling because plaintiffs in qui tam and informer actions have an interest-money they receive if their suit is successful-that may be sufficient to establish an injury in fact as the Court understands it. ${ }^{34}$ Additionally, the Court appears not to have ruled on the constitutionality of these early actions and, as Dean Nichol has recognized, ${ }^{35}$ has refused to decide some lawsuits that it thought raised issues not appropriate for judicial resolution. Finally, the context in which the legislative, executive, and judicial branches operate has changed significantly since the 1790 s. These changes-in particular, the growth of administrative agencies as an arm of the executive branch and the creation by legislatures (and some would say by courts) of numerous rights unknown at common law-may support an understanding of Article III that differs from common law practices. ${ }^{36}$

Dean Nichol also complains that the injury inquiry is il]-suited to separating plaintiffs who have an injury from those who do not. This may be so; certainly, it is not a new criticism. ${ }^{37}$ Difficulty in

Chuch \& State, 454 U.S. 464 (1982); Schlesinger v. Reservists Comm. to Stop the War, 418 U.S. 208 (1974).

31. See, e.g., Flast v. Cohen, 392 U.S. 83 (1968).

32. Nichol, supra note 2, at 1150-52.

33. See, e.g., Cass R. Sunstein, What's Standing After Lujan? Of Citizen Suits, "Injuries," and Article III, 91 MiCH. L. REV. 163, 174-77 (1992).

34. See Lujan v. Defenders of Wildlife, 112 S. Ct. 2130, 2143 (1992) (distinguidhing the asserted rights from "the unusual case in which Congress has created a concrete private interest ... by providing a cash bounty for the victorious plaintiff'); see also Sunstein, supra note 33, at 176 (discussing monetary requirements for qui tam and informer suits).

35. Nichol, supra note 2, at 1156.

36. $C f$. Tennessee v. Garner, 471 U.S. 1, 12-15 (1985) (explaining why the Fourth Amendment may prohibit the use of deadly force to seize a felon despite a common law practice to the contrary when the Constitution was adopted).

37. See, e.g., Valley Forge Christian College v. Americans United for Separation of 
using the established test, however, does not suggest that it should be rejected in favor of something that would open the doors to federal courts by discarding standing limitations. Dean Nichol has to concede, I think, that courts need some way to dismiss suits involving parties whose only interest is ideological combat. ${ }^{38}$ The most likely alternative would be a prudential limitation on suits. Prudential limits would have less legitimacy because they are judge-made and relying on them would also require a reversal of existing law holding that Congress may eliminate prudential limitations through legislation. ${ }^{39}$

Dean Nichol also misreads Defenders as broadly holding that "even though a federal statute sought to bestow standing upon a potential plaintiff, such a grant of jurisdiction [would] violate[] the strictures of the case or controversy requirement." ${ }^{40}$ In fact, as I discussed earlier, the Court recognized that statutes may create legal rights, the invasion of which confers standing; it simply objected to Congress abandoning the concrete injury requirement altogether. ${ }^{41}$ It is also not at all clear that the Endangered Species Act bestows standing on "any person" to sue, regardless of whether that person meets the constitutional requirements for standing. In my view, a literal reading of "any person" in the Endangered Species Act could lead to results that Congress probably did not intend. For example, because the Act defines "person" to include, among other things, employees or agents of foreign

Church \& State, 454 U.S. 464, 475 (1982); 13 WRIGHT \& MILLER, supra note 22, § 3531, at $347-50$.

38. Justice Kennedy's concurring opinion in Defenders identifies important, traditional, structural reasons why courts are not suited to resolve issues in the abstract. Defenders, $112 \mathrm{~S}$. Ct. at 2147 (Kennedy and Souter, JJ., concurring in part and concurring in the judgment); see also Diamond v. Charles, 476 U.S. 54, 62 (1986) (observing that since judicial power can so profoundly affect individuals' lives, liberty, and property, a decision to seek judicial review must be placed in the hands of those who have a direct stake in the outcome and not in the hands of concerned bystanders who will use it to vindicate their value interests).

39. See Warth v. Seldin, 422 U.S. 490, 501 (1975); Center for Auto Safety v. National Highway Traffic Safety Admin., 793 F.2d 1322, 1335-36 (D.C. Cir. 1986).

40. Nichol, supra note 2, at 1146-47.

41. See supra Part I(A); see also Defenders, 112 S. Ct. at 2146-47 (Kennedy and Souter, JJ., concurring in part and concurring in the judgment) (stating that "Congress has the power to define injuries and articulate chains of causation that will give rise to a case or controversy where none existed before, and I do not read the Court's opinion to suggest a contrary view"). 
governments, ${ }^{42}$ it is possible that not only could a visitor to the Bronx Zoo sue the Agency for International Development for failure to consult on a Sri Lanka project, as Justice Scalia hypothesized, but a clerical worker for a Luxembourg ministry of education could do so as well. Like the dissenting court of appeals judge, I do not believe that Congress intended "this provision to be read in a vacuum, without regard to constitutional limitations." 43

I do agree with Dean Nichol, however, that Defenders may be viewed as part of an "agenda" of reducing judicial control over agencies. ${ }^{44}$ I also agree with Professor Pierce that such an "agenda" is not unique to Justice Scalia and not necessarily improper. As Pierce discusses, there are many examples of courts improperly second-guessing agency decisionmaking. ${ }^{45}$ Again, I would add the Eleventh Circuit's air contaminants decision as an example. ${ }^{46}$

I disagree, however, with Professor Pierce's further conclusion that Defenders is part of an "agenda" to reduce the role of Congress in governmental decisionmaking. ${ }^{47}$ This conclusion is based on two questionable premises: First, that Congress, by providing a right for "any person" to sue to enforce any requirement of the Endangered Species Act, intended to eliminate any need to prove particularized injury; and second, that the Supreme Court. "held" that provision unconstitutional. ${ }^{48}$

As I discussed above, I doubt that Congress intended the Endangered Species Act's citizen suit provision to eliminate the particularized injury requirement. ${ }^{49}$ The Court also did not say that the statute was unconstitutional. The general rule is that a court will construe a statute (if it is possible) to avoid doubts as to its constitutionality and will look beyond the literal language of a statute when such language leads to an odd result. ${ }^{50}$ One may

42. 16 U.S.C. \& 1532(13) (1988).

43. Defenders of Wildiffe v. Hodel, 851 F.2d 1035, 1045 (8th Cir. 1988) (Bowman, J., dissenting), rev'd sub nom. Lujan v. Defenders of Wildlife, 112 S. Ct. 1230 (1992).

44. Nichol, supra note 2, at 1166-67.

45. Pierce, supra note 3 , at 1197.

46. AFL-CIO v. OSHA, 965 F.2d 962 (11th Cir. 1992).

47. Pierce, supra note 3 , at 1199.

48. See id. at 1177 .

49. See supra text accompanying notes $41-43$.

50. See Public Citizen v. United States Dep't of Justice, 491 U.S. 440, 454, 465-66 
read the Court's decision, therefore, as implicitly construing the phrase "any person" who may seek judicial review under the Act to mean "any aggrieved person." The Court's discussion of Article III's requirements may have been directed less at Congress and more at the court of appeals, which had stepped out of line in its construction. In this regard, I note that the plaintiff in Defenders did not defend the "procedural rights" part of the court of appeals' decision. ${ }^{51} \mathrm{I}$ also do not believe that other courts of appeals have construed citizen suit provisions to eliminate the Article III injury requirement, ${ }^{52}$ as Professor Pierce appears to argue. ${ }^{53}$ In other words, the Court probably viewed the citizen suit provision of the Act as expressing Congress's intent to provide a private cause of action, but not to abrogate settled rules of standing.

If the Court did hold the statute unconstitutional, however, it may be somewhat misleading to say, as Professor Pierce does, that this is the first time the Court has done so with a statute "that authorized judicial review of an agency action at the behest of members of a statutorily specified class." 54 More than eighty years ago, in United States $v$. Evans, ${ }^{55}$ the Court invalidated a statute on Article III grounds allowing the government to seek review after a criminal acquittal, ${ }^{56}$ and in Director, Office of Workers' Compensation Programs v. Perini North River Associates, ${ }^{57}$ the Court considered (but did not decide) whether the Director's statutory authority to seek review of administrative decisions under the Longshore and Harbor Workers' Compensa-

(1989).

51. See Brief for Respondents, Lujan v. Defenders of Wildlife, 112 S. Ct. 2130 (1992) (No. 90-1424).

52. See, e.g., City of Los Angeles v. National Highway Traffic Safety Admin., 912 F.2d 478, 492-93 (D.C. Cir. 1990) (recognizing that persons suing to enforce National Environmental Policy Act requirements must show a sufficient geographical nexus to the site of a challenged project so that they may be expected to suffer potential environmental consequences); Friends of the Earth v. United States Navy, 841 F.2d 927, 932 (9th Cir. 1988) (same); City of Evanston v. Regional Transp. Auth., 825 F.2d 1121, 1126 (7th Cir. 1987) (same), cert. denied, 484 U.S. 1005 (1988). The cases Professor Pierce cites, Pierce, supra note 3, at 1179 n.51, are not ones in which standing appears to have been at issue; in any event, they predate the Supreme Court's standing decisions from 1976 to present.

53. Pierce, supra note 3 , at 1179

54. Id. at 1178 .

55. 213 U.S. 297 (1909).

56. Id. at $300-01$.

57. 459 U.S. 297 (1983). 
tion $\mathrm{Act}^{58}$ was insufficient to guarantee Article III standing. ${ }^{59}$ Indeed, one would have thought it well settled that Congress can limit, but cannot expand, constitutional standing. ${ }^{60}$

Thus, the idea that Congress cannot abandon the concrete imjury requirement is not a novelty created by Justice Scalia; the principle is well-established. Even judges who may not agree with the result in Defenders do not dispute that principle. ${ }^{61}$

\section{B. The Court's Holding That "Some Day" Intentions and Nexus Theories Are Insufficient to Show Imminent and Particularized Injury to Defenders' Members Was Correct}

The least important of the Court's holdings was that Defenders failed to show an imminent and particularized injury to one of its members. As I discussed earlier, ${ }^{62}$ because Defenders was seeking to prevent harm that had not yet occurred, it had to show that this expected harm was imminent. ${ }^{63}$ It did not do so because the alleged harms-the inability of two members to observe or study endangered species in foreign countries-was dependent on those members going to those countries; the members never showed that such visits were "imminent." The Court's opinion explains why the members' evidence was insufficient at the summary judgment stage. ${ }^{64}$ Professor Pierce's suggestion that no evidence should be required is highly impractical; ${ }^{65}$ it would exempt standing disputes from normal summary judgment rules and require courts to accept as fact whatever a plaintiff puts in a pleading. The Supreme Court has already rejected such an idea ${ }^{66}$

58. 33 U.S.C. \& $901-950$ (1988).

59. Perini North River Associates, 459 U.S. at 304.

60. See Nichol, supra note 2, at $1146 \mathrm{n} .44$ (recognizing dismissal of suit in Muskrat v. United States, 219 U.S. 346 (1911) and the Court's holdings that Article III limits congressional power to create standing, at least in theory).

61. See Lujan v. Defenders of Wildlife, 112 S. Ct. 2130, 2148 (1992) (Stevens, J., concurring); id. at 2160 (Blackmun and O'Connor, JJ., dissenting); see also Center for Auto Safety v. National Highway Traffic Safety Admin., 793 F.2d 1322, 1331 (D.C. Cir. 1986) (Edwards, J.).

62. See supra notes 7-11 and accompanying text.

63. See Defenders, 112 S. Ct. at 2138 n.2.

64. Id.

65. Pierce, supra note 3 , at $1175-76$.

66. Gwaltney of Smithfield, Ltd. v. Chesapeake Bay Found., 484 U.S. 49, 65-66 (1987) (citing United States v. SCRAP, 412 U.S. 669, 689 (1973)) (finding that a defendant may successfully move for summary judgment on the standing issue if he can dem- 
Similarly, the Court was correct in rejecting the plaintiff's nexus theories because, as I discussed above, these theories would have allowed plaintiffs to sue without any proof of injury. Whether or not Congress could create standing by implementing these nexus theories in a statute, as Professor Pierce argues, ${ }^{67}$ it did not do so in the Endangered Species Act. That statute protects plants and animals, not scholars, zoo keepers, or visitors to the Bronx Zoo. Indeed, let us press this point further with the following thought experiment. Imagine that Congress reauthorized the text of the Endangered Species Act but with two changes. First the title-let us imagine that Congress entitled it the Full Employment Act for Scholars. Second, the purpose clause is amended so that the goal of the Act is to keep scholars employed. In those circumstances, I suspect that our tenured student of the Sri Lanka leopard, fearful that his job is vanishing right along with the endangered leopard, would have standing to sue.

\section{DEFENDERS DoEs Not REPRESENT A RADICAL Change IN THE LAW OF STANDING}

\section{A. The Court's Application of the Imminent and Particularized Injury Requirements is Not That Extreme}

In my view, the Court's rejection of the plaintiff's affidavits as insufficient to show imminent injury will largely require only that plaintiffs give greater care to their summary judgment papers. Professor Pierce sees this part of the Court's opinion as "trivial" and "hard to take seriously,"68 and the dissent saw it as doing "little to weed out those who are genuinely harmed from those who are not" and more likely "resurrect[ing] a code-pleading formalism in federal court summary judgment practice." 69

I recently read in the Washington Post that Defenders of Wildlife was challenging the funding of another overseas project that could affect an endangered species; presumably the organization has identified members who can meet the Supreme Court's

onstrate that plaintiff's allegations of standing were a "sham and raised no genuine issue of fact").

67. Pierce, supra note 3 , at 1182.

68. Id. at 1177.

69. Lujan v. Defenders of Wildlife, 112 S. Ct. 2130, 2153 (1992) (Blackmun and O'Connor, JJ., dissenting). 
standing test. ${ }^{70}$ Requiring such putative plaintiffs (and their lawyers) to do their "homework" and particularize alleged injuries is not a trivial exercise. It assists the civil justice system to work effectively. What must be remembered is that the Defenders Court never challenged accepted principles of standing under which organizations can represent members who in turn had a legally protected interest in their "desire to use or observe an animal species, even for purely aesthetic purposes."71 The Court's recent decision in Lucas v. South Carolina Coastal Council ${ }^{72}$ also shows that the "particularized pleading" requirement of Defenders does not apply when standing is challenged at the pleading, rather than at the summary judgment, stage. ${ }^{73}$ Thus the fear that Defenders will keep all manner of worthy plaintiffs from their day in court may prove to be misplaced.

One area where Defenders may have an impact is in tightening the Court's current view of mootness and ripeness which, as I discussed above, may be viewed as time-based perspectives on the injury in fact requirement. At least one court has characterized the imminent harm requirement as "out of kilter" with Supreme Court decisions deeming the "capable of repetition, yet evading review" exception to mootness to be satisfied if the repetition is likely "at any time." ${ }^{74}$ It is also conceivable that Defenders could lead the Court to rethink the ripeness doctrine-originating in Abbott Laboratories v. Gardner" 7 which looks to "the fitness of the issues for judicial decision and the hardship to the parties of withholding court consideration" in approving pre-enforcement review of agency rulemaking. ${ }^{76}$ From the perspective of an agency enforcer, this can only be beneficial. At this point, however, it is speculative to think that Defenders will have such effects.

Similarly, the Court's decision should not foreclose future plaintiffs from showing a particularized injury based on some

70. Groups to Sue Interior Over Dam in China, WASH. PosT, Jan. 1, 1993, at A12.

71. Defenders, 112 S. Ct. at 2137.

72. 112 S. Ct. 2886 (1992).

73. Id. at 2892 n.3 (noting that the challenge to standing in Defenders would have been unsuccessful if, as in Lucas, it had been made at the pleading stage). But see id. at 2907 n.5 (Blackmun, J., dissenting).

74. Christian Knights of the Ku Klux Klan v. District of Columbia, 972 F.2d 365, 371 (D.C. Cir. 1992).

75. 387 U.S. 136 (1967).

76. Id. at 149 . 
nexus theory. They just need a statute that explicitly creates such a nexus within the limitations of Article III's injury in fact requirement.

\section{B. The Court's Article III Injury in Fact Requirement Should Not Limit Congress's Power to Create Legal Rights by Statute}

Given the apparent ability of environmental groups to meet Defenders' factual requirements, it is difficult to see how Defenders will have a significant impact on environmental litigation. All it might mean is that groups challenging actions that threaten some damage to the environment must prove that one of their members has sufficient nexus to the geographical area where damage is threatened. As I discussed earlier, this was generally the law before Defenders, and Defenders did not change it. ${ }^{77}$ Professor Pierce's contrary view is premised on the questionable assumption that the Court found the citizen suit provision of the Endangered Species Act unconstitutional, from which he concludes that this ruling will apply to other environmental statutes (some of which require that the plaintiff be aggrieved or have an interest affected), ${ }^{78}$ with the result that only regulated firms could prove a concrete and particularized injury.

I think it even less likely that the Freedom of Information Act (FOIA) could be affected. ${ }^{79}$ That statute is an example of Congress creating a right for a class of persons ${ }^{80}$ and providing a means of enforcement for any person "adversely affected or aggrieved by agency action." ${ }^{81}$ Justice Scalia has long recognized that the right to judicial review is clear where a statute "requires an agent of the executive to provide a particular benefit directly

77. Compare Lujan v. National Wildlife Fed'n, 497 U.S. 871 (1990) (before Defenders, plaintiffs' use and enjoyment of land in the vicinity of land covered by agency actions was insufficient to create standing) with Supporters to Oppose Pollution v. Heritage Group, 973 F.2d 1320, 1322 (7th Cir. 1992) (after Defenders, group representing persons living close to landfill has standing).

78. Pierce, supra note 3, at 1188-89; see, e.g., 30 U.S.C. \& 1270(a) (1988) (Surface Mining Control and Reclamation Act); 33 U.S.C. $\& 1365(\mathrm{a})$, (g) (1988) (Federal Water Pollution Control Act).

79. See Pierce, supra note 3, at 1189-90.

80. 5 U.S.C. \& 552(a)(3) (1988) (designating that upon proper request, agencies "shall unake [certain] records promptly available to any person").

81. Id. \& 702 . 
to a particular individual."82 The defect in the Endangered Species Act was that Congress had not created a comparable right. Instead, it placed on agencies a duty to consult before funding projects that could affect plants and animals; it did not specify how this duty created or affected any rights in a human plaintiff. ${ }^{83}$

Finally, I think unfounded Dean Nichol's and Professor Pierce's fears that Defenders will have major effects beyond environmental law and FOIA, in particular their argument that only regulated firms will have standing to challenge agency action and that, therefore, agencies will be captured by regulated interests. ${ }^{84}$ The premise for their argument appears to be that Defenders changed the law on Article III standing to create an injury requirement that will be impossible to meet in most cases. ${ }^{85}$ As I have shown, Defenders did not change the law; moreover, its test is not difficult to satisfy. In fact, as the Court has recognized, it is consistent with the test normally applied for individuals seeking review of final agency action, which requires that they be adversely affected or aggrieved by it. ${ }^{86}$

I have argued for a modest interpretation of Defenders-that Congress when it passed the Endangered Species Act was not specific as to what the injury was, and that Congress cannot just authorize citizen suits, it must specify who has an injury. In this regard, I do not read Justice Scalia's opinion in Defenders as stating that the Court can veto Congress if Congress goes "too far" in extending standing. Although that may be the learning of Justice Scalia's 1983 article, ${ }^{87}$ it is not the necessary, or even preferred, ratiocination of the Defenders opinion.

But let us take the "robust" reading of Defenders put forth straw-man style by Dean Nichol and Professor Pierce. Is it, as a cautionary set of limits, so obviously off-course? I think not. My

82. Scalia, supra note 21 , at $885-86$.

83. See Lujan v. Defenders of Wildlife, 112 S. Ct. 2130, 2143 (1992) (characterizing right to sue as "abstract, self-contained, non-instrumental"); id. at 2147 (Kennedy and Souter, JJ., concurring in part and concurring in the judgment) (stating that Congress at least has to identify the injury and relate it to a class of persons entitled to sue).

84. See Nichol, supra note 2, at 1168; Pierce, supra note 3, at 1194-95.

85. See Pierce, supra note 3 , at 1192.

86. See Middlesex County Sewerage Auth. v. National Sea Clammers Ass'n, 453 U.S. 1, 16-17 (1981).

87. Scalia, supra note 21. 
main point is a simple one, but I am a bit skittish of saying it-you cannot deconstruct the Constitution. Even Congress cannot do so. It is interesting that Professor Sunstein himself recognizes this. He affirms that there are "limits to Congress' power to decide what is a 'case' or 'controversy." "88 Thus he admits:

In all likelihood, for example, Congress is barred from overcoming the ban on advisory opinions. This ban is a plausible inference from the "Opinions in Writing" Clause, which allows the President to require opinions from heads of departments, but not from judges. Moreover, the notion of a "case," as historically understood, excludes the judicial provision of advice at the behest of public officials. ${ }^{89}$

This, then, is the whole ball game. Congress cannot redefine at will the "core" meaning of terms such as "advisory opinions" or "cases and contoversies." The judiciary's assigned constitutional role is to adjudicate "cases and controversies"-a term which, although amenable to a variety of meaning, is not open-textured. This admittedly structural perspective is but one modality of constitutional argument. Nonetheless, whereas the outer limits set by Defenders will not, in practice, affect most lawsuits, it offers an important, heuristic, constitutional truth. ${ }^{90}$

88. Sunstein, supra note 33 , at 179 n.79.

89. Id. (citations omitted).

90. See generally PHILIP BOBBITT, CONSTITUTIONAL INTERPRETATION (1991); PHILIP BobbitT, Constitutional Fate: THE Theory of the Constitution (1982). 